\title{
The Memory Library: How the Library in Hellenistic Alexandria Worked
}

\author{
Ole Olesen-Bagneux
}

University of Copenhagen, 6 Birketinget, DK-2300, Copenhagen, Denmark, <blt526@iva.ku.dk>

\begin{abstract}
Ole Olesen-Bagneux holds an MLISc and began his Ph.D. in 2011 at the Royal School of Library and Information Science, now part of the University of Copenhagen. In the fall of 2012 he studied at Anthropologie et Histoire des Mondes Antiques in Paris, affiliated both at L'École des Hautes Études en Sciences Sociales at the Sorbonne. Here, under fruitful guidance by Professor Christian Jacob, he spent some very long days reading in the Bibliothèque Gernet-Glotz. He also followed Jacobs's courses on his theory of places of knowledge (lieux de savoir).
\end{abstract}

Olesen-Bagneux, Ole. The Memory Library: How the Library in Hellenistic Alexandria Worked. Knowledge Organization. 41(1), 3-13. 37 references.

Abstract: For millennia the famous library in Hellenistic Alexandria has been praised as an epicenter of

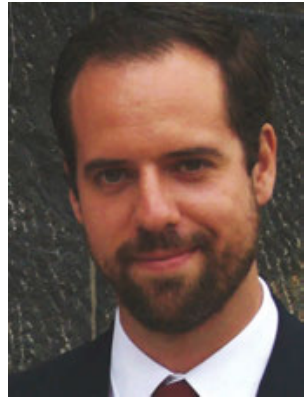
enlightenment and wisdom. And yet, a question still seems unanswered: how was its literature classified and retrieved? It is a subject that has been given surprisingly little attention by the field of library-and-information science-indeed, by scholarship in general. Furthermore, a certain way of thinking has influenced the few answers that have so far been attempted. It is as if the scholars of our era have tried to identify the modern, physical library in the Hellenistic library in Alexandria. But such an approach is biased in a basic way: It simply does not consider the impact of the cultural and intellectual context of the library. This article differs fundamentally, because I reject the notion that the library was like those of today. Accordingly, an entirely new way of understanding how the library actually worked, in terms of classification and retrieval processes is presented. The key element is to understand the library both as a physical structure and as a structure in the memory of the Alexandrian scholars. In this article, these structures are put together so as to propose a new interpretation of the library.

Received 21 August 2013; Revised 25 October 2013; Accepted 29 October 2013

Keywords: library, memory, literature, Pinakes, Aristophanes, mechanics, scholars, Alexandria

\subsection{Introduction}

Very little is known about the ancient library of Alexandria. Sources indicate that it could have contained between 40,000 and 700,000 scrolls (Staikos 2004). Nor can it be ascertained exactly when it was established but it must have been shortly after 300 BCE. It is reasonable to accept that it must have looked something like its later rival, the Attalid library in Pergamum, erected around 200 BCE. We have rather firm knowledge about its architecture (Hoepfner 2002). The library in Alexandria was part of a religious institution, the Mouseion, and the scholars were in fact extremely skilled slaves that were imprisoned within the Mouseion. Attempted escape could be penalized by death (Canfora 1990), and part of the poetry written by these locked-up scholars was performed during religious ceremonies (Meillier 1979).
It seems quite obvious, that the ancient library of Hellenistic Alexandria was not like a modern library-not at all. Nevertheless, the library has been misinterpreted, quite substantially, by modern scholarship as though it had been similar to modern libraries. This can be seen in the descriptions of how the library worked, of how classification and retrieval was conducted within it. In his book $L i$ braries in the Ancient World Lionel Casson (2001, 41) provides such a description. He writes about the Pinakes by Callimachus, calling it: "A key to the vast collection: from his Pinakes users could determine the existence of any particular work; from his shelf-list they could determine its location. He had created a vital reference tool."

Casson claims that the Pinakes was not the catalog of the library, but merely a sort of bibliography, a point of view that contradicts that generally accepted. Casson believes that a specific list was not integrated in the Pinakes, 
and that this list was the catalog (Casson 2001, 153). This is pure assumption, no actual evidence of this can be found. It is as if Casson reproduces a modern distinction between catalog and bibliography in antiquity, as if he seeks to confirm the link between libraries in modern times, and libraries in antiquity. It makes little sense to accept Casson's view since it builds on the assumption that the Alexandrian scholars would maintain complex, unnecessary and time consuming workflows in retrieving the literature in the library, for no actual reason. Konstantinos Staikos $(2004,186)$ expresses the generally accepted view of the Pinakes: "What Callimachus set out to do was to compile a comprehensive 'bibliographical' list of authors and their works that would also serve as a library catalogue. The result was the Pinakes." Although I agree with Staikos, I believe that he describes only a part of how the library worked. And even though he differs with Casson, he thinks like him: He uses exclamation points for the word bibliographical, knowing that he pushes a point further than what Callimachus himself would have understood.

Scholarship on the Alexandrian library is heavily biased by the unfruitful desire to retrieve elements similar to those present in our own era. It is as if we want to know what constituted the bibliography of the Alexandrian library instead of trying to grasp what the Pinakes actually was in its own respect. Both Casson and Staikos thinks of the library of Hellenistic Alexandria as a modern, physical library, totally uninfluenced by the intellectual principles of the Greek past it was dedicated to protect. Staikos $(2000,67)$ goes so far as to claim that: "Quite possibly the 'philosophy' underlying the Pinakes was entirely Callimachus's own idea and owed nothing to the cataloguing methods employed by the Peripatetics at the Lyceum in Athens or the methods devised by the Babylonians for use in their great collections of archives."

I think that the specific assumption might be correct, that the Peripatetics and the Babylonians did not influence Callimachus. Nevertheless, with this assumption at hand Staikos (2000) simply denies that the entire intellectual heritage played any role whatsoever in the way the Alexandrians organized their library. And that, I think, is not correct. Like Staikos, Phillips (2010) believes that the Alexandrian library was more in contact with our present reality than the Greek era that had just ended. Phillips (2010) even goes as far as to conclude that the library of Alexandria simply was the first modern library in the world, since it had all the characteristics of a modern library!

I disagree fundamentally with the view represented by Staikos (2000), Casson (2001) and Phillips (2010). They are blinded by the many centuries of human civilization that divides the present from the $3^{\text {rd }}$ and $2^{\text {nd }}$ century BCE
Alexandrian reality. And so unfortunately they all just basically conclude that the Alexandrian library worked like a modern, physical library.

Instead of searching for elements similar to modern ones, my analysis turns the perspective around. I will argue that the way the library in Hellenistic Alexandria worked was in fact the result of a close and functional connection with the Greek past it also contained. I believe that the key to understanding the library lies in the story about Aristophanes of Byzantium (Jacob 2010). In this story, it is claimed that Aristophanes knew the structure and content of the library by heart. Accordingly, I agree with Christian Jacob $(2010,11)$ on the nature of the memory of Aristophanes, i.e. as a mental construct that somehow matches the library. But I think it is a demonstration of how the library worked, not only for Aristophanes, but for the scholars in general. Therefore, Jacob's view is followed in this article, but his considerations are widened and supported with evidence.

The main body of the article has three parts. The first part is called The Dead Library. In antiquity, physical text was considered to be related to death (Svenbro 1988). Accordingly, The Dead Library deals with the physical structure-the actual library-of organized texts. It examines how the physical scrolls were classified and retrieved. But the reader must have in mind that this was not how the library worked-only an aspect of how it worked! The second part is called The Living Library. Human beings were called living libraries in antiquity, if they could remember impressive amounts of literature (Too 2010). Therefore, The Living Library analyzes the scholar in antiquity, how he or she was able to store, search, remember and quote enormous amounts of literature from memory. Finally, the third part is called The Memory Library. This third part melds the dead and the living library into one constellation, and claims that this was how the library actually worked. In this part, I argue that the library, be it in memory or the actual physical library could be sung. "The memory library," is a new term, and yet, the Greek word

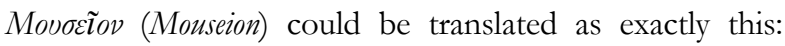
"Memory library."

\subsection{The Dead Library}

As mentioned above briefly, death and written text was considered to be closely connected in Greek antiquity. Actually, the written testimonies of a person, in modern times we would call this the collected works of an author, were viewed as the true tomb of the person leaving them behind. These written testimonies simply outmatched the sepulchral monument representing a person that died (Platthy 1968, 96). More recent studies have shown that the link between death and written culture evolved in an- 
tiquity (Svenbro 1988, 13) and culminated in a refined literary wave coined as the Alexandrian avant-garde (Bing 2008, 144-145). The remarkable esthetics of that wave regarded a library as an enormous graveyard, containing the true sepulchral monuments of the writers now dead. Thus, the physical library in Alexandria in Hellenistic times is called "the dead library." In the following, I will describe how the dead library was organized.

\subsection{Zenodotus}

Zenodotus of Ephesus (330-260 BC) was most likely the first director of the library in Alexandria. It is believed that he refined the organization of the library extensively, since he was able to conduct a complete and critical version of Homer. And in order to do so, the different versions of Homer had to be strictly organized. So, he probably divided the holdings of the library into at least two categories, or, at the very least he created a principle of division that was later to be followed. These two categories were critical edited texts and different versions of the same text that were yet to be compared in order to establish the critical edition. It has been argued that Zenodotus divided texts into classes that followed a classification scheme (e.g. Casson 2001, 37-40) but this argument is not supported with evidence, besides the accepted assumption that Zenodotus must have created a list of inventory that mentioned each scroll contained in the library.

Along with this division came a more frequent use of the Sillybos-the little note that was attached to each scroll, with information that in modern times would be called metadata. The Sillybos would hold the title of the first text or more likely the incipit (the first words of the text). It would also hold the stichometric sum that was the total number of lines, stichos, in the Homeric verses. Originally, the stichometric sum was used to control production of text-it originated from classic Athens and was not invented in Alexandria. People knew that a certain song was a certain number of lines long, and thus the total sum of lines indicated whether the scribe had conducted honest labor (Witty 1958, 134). The Alexandrian scholars invented a new way of using the stichometric numbers, as we shall see below. The Sillybos would also hold the name of the critical editor, for example the "Zenodotus version." This indicates frequent use: all texts were to be critically edited at some point.

Quite certainly, the library was arranged alphabetically from the start, since Zenodotus left proof that he was familiar with alphabetization (Casson 2001, 37-40). But this was only alphabetization by the first letter. This way of alphabetizing has been subject to speculation (e.g. Blum 1991, 227) because it is uncertain whether it was the first step towards complete alphabetization, or whether it contained a potential in its own respect, different from complete alphabetization.

\subsection{Callimachus}

Callimachus of Cyrene (305-240 BC) was probably not the director of the library, but he had substantial influence on its organization. In this respect, his is famous for com-

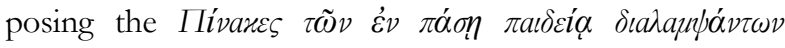
(Pfeiffer 1949), that translates thus: Tables of those who distinguished themselves in all branches of learning and their writings. It is usually just referred to as Pinakes, its first word in Greek, meaning table or board. It should be mentioned though, that Callimachus composed several Pinakes (Witty 1973). The Pinakes consisted of 120 scrolls and contained information about writers and their works. It has been characterized as so many different genres-literary encyclopedia (Lerner 2001, 29), register of literary matter (Cancik et al., 1996-), catalog (Staikos 2004, 186), biobibliographical catalogue raisonné (Witty 1958, 132) bibliography (Jacob 2007, 1127), biobibliography (Blum 1991, 1) - that it would probably be most suitable to define it as a genre of its own, pinakography, as mentioned but refuted by Blum (1991, 9). Although Blum (1991) is right, when he describes the Pinakes as a biobibliography, Callimachus would not have had a clue about the meaning of such a word, at least not as a literary genre. It blurs the analysis of what might have been Callimachus's intention with his work when it is categorized as something that did not exist in his era. The aforementioned attempts to categorize the Pinakes as genres that were not yet invented but basically just labels it with a retronym that does not answer what it was in its own respect. Nevertheless, the problem of genre clearly demonstrates that it is difficult to ascertain what the Pinakes was. It has not reached us; it is lost, but we have testimonies of its existence and content (Witty 1958, 133-36) that can enable a discussion with scientific authority.

The Pinakes was divided into classes and three are known with certainty: Law, rhetoric and miscellaneous. Another seven seem likely (Witty 1958, 136; Pfeiffer 1949, 349) creating a total of ten classes. Most likely even more than ten classes existed and different assumptions have been made as to try to imagine the totality of the classes of the Pinakes (e.g. Parsons 1952, 204-19). Each class would be divided into subclasses, though they were divided in different ways: chronologically, topographically and biographically (Pfeiffer 1968, 129). The number of classes and their subdivisions is not that important to my point. The fact that the classes matched a certain area of the library is-which is a generally accepted assumption (e.g. Staikos 2004, 186). That a work was placed within a 
certain class in Pinakes meant that it was located in the area or room of this class in the library. Each entry in the Pinakes simply matched a physical location.

The list of inventory by Zenodotus was perhaps used as a catalog in the library (Casson 2001, 37-40) Even though Blum (1991) has been criticized substantially for his research (e.g. Barnes 2000, 77) he makes several very qualified points, one of them being the different nature of the list of inventory by Zenodotus and the Pinakes by Callimachus. A list of inventory only mentions a scroll in such a way that it is retrievable. That was not the case with the Pinakes. Consider the title: Tables of those who distinguished themselves in all branches of learning and their writings. BIum $(1991,226)$ points to the fact that scrolls containing more than one author or several works, or even both, were not described with satisfying precision in the list of inventory. It did not inform about the writers or works contained in the library, only the scrolls. But the Pinakes on the other hand, mentioned all those who distinguished themselves in all branches of learning and their writings. It was without doubt the Pinakes that became the library "catalog," since it was the tool that mentioned all writers (or those who had been written down by others) and what they had written (or what others had written down). Each entry in the Pinakes would start with a short biography of the writer, and then mention his works. Each work was mentioned by its title or incipit, the stichometric sum, and the number of books (scrolls) it consisted of. This information was also indicated on the Sillybos, as mentioned above. This permits the first description of the library mechanics. From the class in the Pinakes one knew what area of the library to go to, to find a given author, and from the information in that same author's entry in $\mathrm{Pi}$ nakes, one could even locate the exact scroll.

Most likely, the library mechanics had a step between the area and the work of the author. This step was the place of the specific author. Very little can be said with precision about this, but many sources indicate such a step. In Pergamum, for example, the library of the Attalid kings had sculptures representing authors (Callmer 1944, 150-151), that were perhaps located close to that author's scrolls (Hoepfner 2002, 49). The word pinakes is itself another indication, since it probably originally meant boards or tables hung on the shelves or walls of the library, to indicate the same information as the Pinakes by Callimachus. It is also possible to grasp the place of the author due to impressive research by Gaëlle Coqueugniot (2007). She concludes that the word kibôtos most likely was the common description of the entities that contained scrolls (Coqueugniot 2007, 304) even if these entities were different in size and shape (box, bag, coffin or shelves). Accordingly, Coqueugniot discusses the many possibilities of translation of the word kibôtos into French, and the same thing can of course be done in English. "Container" has been chosen here.

But if authors in a given class were given a specific place, wouldn't it become impossible to keep that place as the collection grew? This is where alphabetization by only the first letter comes into play. More writers could simply be added in the end of the list in Pinakes (under each letter, that is) and simultaneously be given their own container in the room to which they belonged. This again makes it probable that the containers or places of authors were recognizable visually, by tables or sculptures because crowded rooms by nature leave little space for orientation. This way of ensuring solid structure through flexibility was a sort of upside-down-Dewey that permitted writers to be located in the same spot almost to eternity (though, only in the logic of the slow text production, i.e. preGutenberg).

\subsection{Aristophanes}

Aristophanes from Byzantium (ca. 260- 185 BC) is normally (e.g. Staikos 2004, 181-182) not considered as a contributor to the innovation of library mechanics in Hellenistic Alexandria. He updated the Pinakes into a new version, which is not regarded as significant. But in fact, two important things happened during his time as director of the library.

The first thing is very simple, and yet its implication is substantial. The stichometric note as mentioned above was only described as indicating a total sum. Evidently, keeping track of, say, 12.739 lines only in the mind was a tough job while at the same time copying a text. Therefore, the scribes noted the stichometric numbers continuously, like small signs next to the column of text. The system was like this: $A=100$ lines; $B=200$ lines; $\Gamma=300$ lines; $\Delta=400$ lines and so on. In Athens, the stichometric sum was proof of honest labor, but in Aristophanes' time as director in Alexandria, the stichometric numbers along the text began to be used as references, just as in modern times we use references to chapters and pages (Irigoin 2001, 24-26). The stichometric number helped indicate which part of the text was requested.

The second thing is not traceable in the mechanics of the dead library. It will become clear in the next part, "The Living Library," that it played a central role in the mechanics in the living library, and for the memory library as a whole. And since it dealt with the written language, and was carried out by Aristophanes it is mentioned here. Aristophanes reformed the Greek language. He introduced a more stringent and frequent use of diacritical signs (they already appear in writings from classic times). These signs, above and around the letters of the Greek language helped demonstrate how syllables are pronounced (Irigoin 2001, 
42). It is very likely that Aristophanes reformed the language in such a way because Alexandria was a cultural melting pot, attracting scholars from as far as India. These foreigners needed help to adapt to the Greek language, which had not been the case in classical Hellas, where the intelligentsia had Greek as their first language (Canfora 1992, 20-21). It is not a mistake for the reader to compare Aristophanes' reform with the difference between written UK and US English. But the diacritical signs were not employed at each syllable where they should have been according to pronunciation. This has been quite a mystery to modern scholars. It is evident, that they symbolized a system, and that they were much more frequent than in the classical era. But what was the principle of their employment? Gregory Nagy $(2000,9)$ has resolved this problem, by turning the modern philological editing of manuscripts from the time of Aristophanes into a philological study itself. What he saw was that modern editions of these manuscripts blurred an understanding of the diacritical signs in relation to the original meter, in this case the metric cola, a meter that most likely was introduced by Aristophanes himself. Originally, the diacritical signs expressed the rhythm of the metric cola. Put simply, a line played out a melody:

\begin{tabular}{|c|c|c|}
\hline Line & $\begin{array}{l}\text { The colometric mel- } \\
\text { ody (col. X (VIII)): }\end{array}$ & $\begin{array}{l}\text { Modern layout (col. } 12 \\
(8) \text { ): }\end{array}$ \\
\hline \multirow[t]{2}{*}{85} & $\begin{array}{l}\alpha \mu \varphi \imath \tau \varrho \nu \omega v i \dot{\alpha} \delta \alpha \sigma^{*} \\
\varepsilon i \pi \varepsilon v \tau \varepsilon \varepsilon^{*} \tau \iota \sigma \alpha \theta \alpha \nu \alpha \tau \omega \nu\end{array}$ & 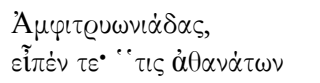 \\
\hline & $\begin{array}{l}\text { Above, the diacritical } \\
\text { signs have been used to } \\
\text { point out the rhythm } \\
\text { of the entire colon. } \\
\text { Each colon is ex- } \\
\text { pressed as a unit, al- } \\
\text { most as if it was one } \\
\text { word. }\end{array}$ & $\begin{array}{l}\text { Above, the diacritical } \\
\text { signs have been used to } \\
\text { explain the pronunciation } \\
\text { of each syllable. Each co- } \\
\text { lon is expressed staccato, } \\
\text { the readability is height- } \\
\text { ened, but the melody is } \\
\text { lost. }\end{array}$ \\
\hline
\end{tabular}

Table 1: The colometric melody
Nagy calls this melody the colometric melody. It was probably a part of the library mechanics of the living library, as we shall see below.

\subsection{The mechanics of the dead library}

To sum up, the mechanics of the dead library evolved into a six step procedure around 200 BC. From the Pinakes, one was led to a specific room via the class of literature. In the room (or area) a sculpture or tablet made the containers visually recognizable, this led the scholar to the author. In the container, work and scroll could be identified by information on the sillybos that matched the information in the entry in Pinakes. Furthermore, a specific part in the scroll could be located via the stichometric numbers. This is demonstrated in Figure 1.

\subsection{The living library}

Opposed to the dead library was "the living library." The term actually occurs in literature from antiquity, and as a phenomenon it was current. The living library was a scholar, capable of remembering a large amount of literature-a feature that can most likely be interpreted as a heritage from the rhapsodes of archaic Hellas. But it had a significant difference: not only did the scholar remember the literature, he also remembered its location, both in memory and in a physical library. The literature contained in the memory of the scholar mirrored the physical library, as though the physical library were imagined each time a work was sought. Testimonies of living libraries actually indicate that they began to occur just about the time when the mechanics of the dead library was in place. The aforementioned Aristophanes from Byzantium was a living library (Jacob 2010, 11), and he will be analyzed as such in the following. But the mechanics of the living library are approached in reverse chro-

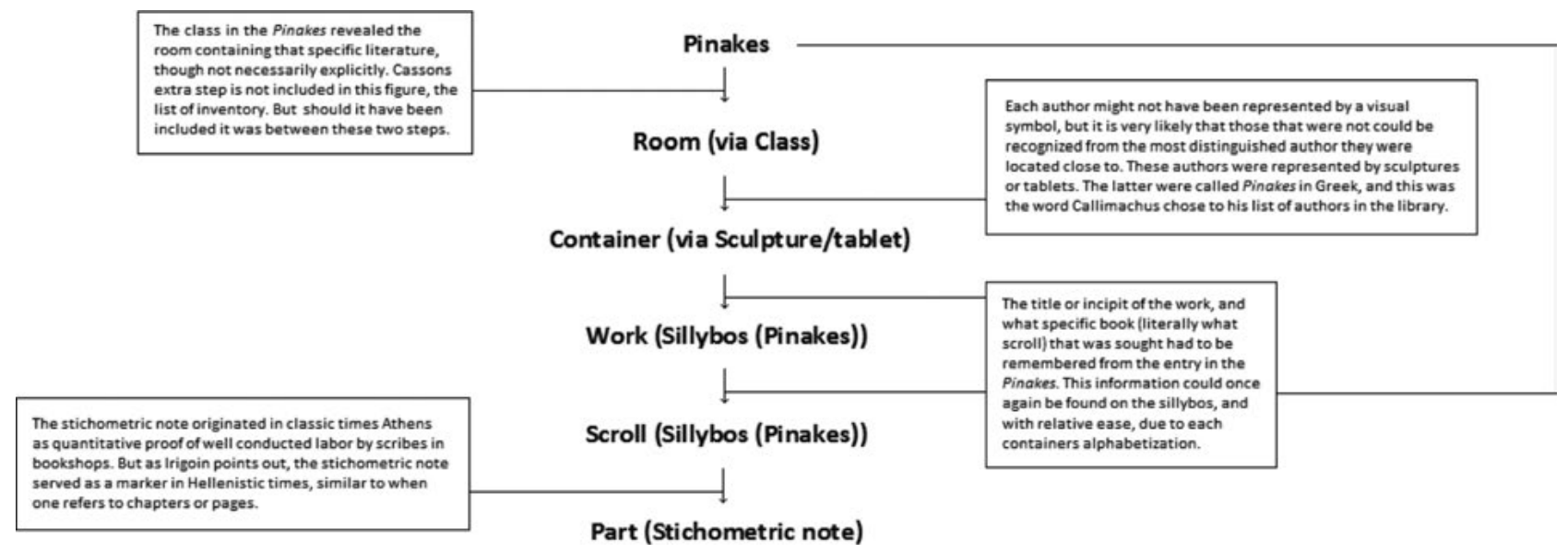

Figure 1: The mechanics of the dead library 
nology, simply because that explains it in the clearest way. And so, we begin with Athenaeus.

\subsection{Athenaeus}

Not until the late Roman period does the literature that has reached us reveal the mechanics of the living library. Athenaeus of Naucratis (2nd century CE) was a Greekspeaking scholar living in Rome. He composed the work

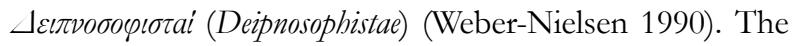
title translates in two ways: The Dinner-table Philosophers and Experts of the Dinner-table. Its Greek title is kept here to illustrate both meanings, because they are both important in this context. The Deipnosophistae is in many ways the key to literature in antiquity, since large quantities of literature have reached us only through this work by Athenaeus. Instead of writing on his own, Athenaeus composed a story that enveloped enormous amounts of already existing literature. In order to do so, he needed a course of events, and he chose an almost never-ending banquet as the setting. As delicate servings were carried in and out the scholars were stimulated in various ways. When they were starved and impatient, accusations rose around the table. When new and surprising plates were served, the scholars joyfully exclaimed their happiness. The scholars described each event with long quotations from literature, and they quoted that literature from their memories.

Before proceeding further with the analysis of the Deipnosophistae, it should be mentioned, that a certain tradition of interpretation will not be followed, nor accepted, in this article. This tradition basically interprets the Deipnosophistae as a messy work, symbolizing cultural decay (e.g. Too 2010, 114) It is correct that the overall story lacks compositional unity (Weber-Nielsen 1990, 8-9) and that these rather unimportant, small details can indeed serve as the foundation of many a pedantic-analytical critique, pinpointing obvious mistakes as though that were the sole purpose of the humanities. Instead, let's look at this enigmatic treasury that Athenaeus was so kind to leave us, let's see what he was up to, had in mind.

Christian Jacob analyses the Deipnosophistae in The Web of Athenaeus (2013) in an original way. He regards the memorized literature as a sort of common web that the scholars energetically and constantly peruse during the eternal dinner. What motivates them is zetesis, the urge to explore something in depth. It is not entirely impossible to describe how this urge unfolded, how the web of Athenaeus worked. The scholars seem to browse important writers on different subjects, lists of words, of places or quotations, and they correct each other when they cite them wrong, again demonstrating that this web was universal in some sort. If they cannot agree, the written text appears as the concluding authority. Jacob begins his book with the ex- ample cabbage. The cabbage, like everything else, opens a universe of literature, and so, comic poets, philosophers and experts in plants are cited in an elegant continuous composition that describes ... cabbage! Each scholar perused the web of literature in a non-linear pattern, zapping between authors, browsing each author's work, in the sense the subject is described here, in this way, and here again, in that way and so on and so on. The sum of all those patterns constitutes the conversation in the Deipnosophistae.

The scholars, the living libraries, were able to quote exact phrases and the occurrence of words. When they went into zetesis mode, and searched their web of literature both the sound of words and their visual representation were in play. While Jacob grasps the refined complexity of the web of Athenaeus, the general assumption that both sound and visual representation of words or phrases played a vital role for the mechanics of the living library is generally accepted (e.g. Carruthers 2008, 101). Included in the sounds is of course the colometric melody, but as Jacob clearly demonstrates, by the time Athenaeus composed his Deipnosophistae the skills of the living library had evolved substantially.

\subsection{Aristophanes—once again}

At this point, we are able to go back in time, and once again look at the merits of Aristophanes from Byzantium (ca. 260-185 BCE). As already mentioned, Aristophanes was a living library (Jacob 2010, 11). This is documented in Vitruvius's treaty on architecture De Architectura (Jacob 2010). Vitruvius tells the story of a poetry contest held at the court of the Ptolemaic court in Alexandria, when Aristophanes was a young man. The contest was a recitatio and thus, in the literary history it is to be understood as a public performance with its roots in the tradition of the rhapsodes, and the private reading aloud of poetry amongst friends that was to become common in Rome. Contrary to the rhapsodes the person performing in recitatio read aloud from manuscript, and contrary to what was to become the habit in Rome, it was still done in public.

Aristophanes-so Vitruvius tells —was appointed leader of the library because he was able to expose the contestants in the competition as cheaters. They were not poets; all but one had copied text from various authors in the library, simply claiming that it was their own poetry. Aristophanes recognized the poetry and was able to tell who had originally composed it. To prove his point, relying only on his memory, he had an endless amount of scrolls taken out of the library. He knew where they were stored and was able to find the exact lines that had been copied, and compare the texts of supposed poets with the originals.

This story has many different layers. It discusses plagiarism, but the topic has to be perceived in the light of the 
slow death of oral transmission where borrowing words from the past was no crime. It describes the cultural rivalry between Alexandria and Pergamum, where Vitruvius favors the library architecture of Pergamum most likely due to that city's strong bond with Rome. It is also a symbol of the literary wave of the Alexandrian avant-garde, since Aristophanes refutes the old-fashioned poetry by the fake poets that pleases the audience but lacks esthetic refinement. On top of that, Vitruvius most likely enhanced the capabilities of Aristophanes' memory to add a little drama to the story. So, all in all, Vitruvius is a source that has to be dealt with respectfully, but not naively. Considering Aristophanes as a living library, one has to have all this in mind.

Indeed, Aristophanes was a living library. How does he expose its mechanics? The story indicates that he was capable of recognizing poetry, literature in general, in its exact phrasing. This seems very similar to the fact that he used the diacritical signs to make colometric melodies, as described above. These melodies must have been part of a learning-by-heart memorization that he to some extent could recognize when they (together with other meter) were pronounced or sung by others. The story also tells us, that he was capable of retrieving the scrolls in the library containing the melodies-from memory!

\subsection{The mechanics of the living library}

Athenaeus and Aristophanes permit a general description of the mechanics of the living library in the Hellenistic era. The essential element is the colometric melody. Its existence can be ascertained as a part of the mechanics of the living library via Vitruvius, as mentioned above. It is likely, though, that other structures such as entire phrases or even longer quotations from texts were also included in the mechanics of the living library. A basic cognitive assumption is that the longer the quotation, the easier it was for the living library to recognize the author. Also, words might be considered. Certainly, the living libraries in Athenaeus's Rome were capable of perusing their mental web for specific words. It might already have been the case in Hellenistic Alexandria, since Aristophanes wrote the Lexeis, the first reference tool on the basis of words. But one should really be careful about claiming the beginnings of the understanding of words as phenomenon in antiquity (Small 1997).

Browsing words (or the occurrence of words) or colometric melodies are marked with horizontal arrows, in Figure 2 below. In a rather primitive way this illustrates the process of zetesis, that the living library is exploring a mental constellation of literature. The mechanics of the living library can be illustrated by this figure.

A final remark: How common was the living library? There is no point in trying to give a precise answer; too little evidence has reached us. Nevertheless, an evolution can be glimpsed. Aristophanes was appointed director of the library due to his capabilities. In this context it does not matter whether this actually happened or not: the story itself testifies that Aristophanes as a living library must have been a rare sight around 230 BCE Alexandria, or at least that he mastered the role of the living library like no other. On the other hand, in second century CE Rome, the living libraries gathered in literary discussion around the dinner-table in Athenaeus Deipnosophistae. The story is fiction, but the setting seems like a common event, only stretched in time to the extreme. At one point $(V-203 e)$, a person even comments on the Alexandrian library, saying that he does not bother to describe its architecture and content since it is in the memory of everyone. Quite possibly, the living library was to begin with a rare and exclusive phenomenon that over the centuries became more and more common, as literacy increased.

\subsection{The Memory Library}

As the story of Aristophanes demonstrates, the mechanics of the living library somehow blended with the mechanics of the dead library. Aristophanes could browse his memory for quotations by authors and he could afterwards locate them in them library. Jacob (2010) claims that this was exactly the case. Such a skill is also testified by Pliny the Elder in his Naturalis Histioria although the linking between living and dead libraries is often not grasped (e.g. Yates 1965, 41).

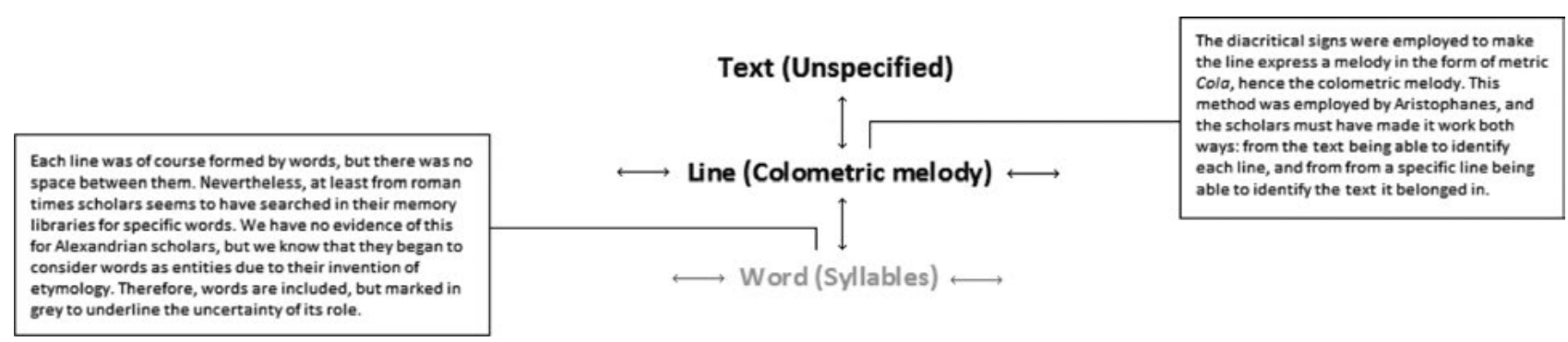

Figure 2: The mechanics of the living library 
I have presented the dead and living library as I think they must have worked. I will now proceed to argue that they were in fact combined, not by extraordinary coincidence or skill, but as one logical system, that I will call the "Memory Library," since it relied on human memory and

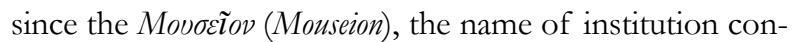
taining the library in Hellenistic Alexandria, can be translated as such. I believe that the memory library was a structure that existed both in the memory of the scholars and as a physical library. Instead of pushing the semimodern library's reality back in time, claiming that it to some extent existed in the Alexandrian library, as do Phillips (2010) Casson (2001) and Staikos (2000), I will now do the contrary. I believe that the memory library that I am about to describe below was a logical continuation of Greek scholarship in antiquity. I will present what I think is the most important argument in my favor, namely the argument of the human voice (two other essential arguments are mnemonics and literary theory). The argument of the human voice is simply this: The scholars could sing the entire library. Below, I qualify how.

\subsection{Singing the literature in the library}

Nagy (2000) is not the only one concerned with literature in antiquity as sound. In his books Preface to Plato (1963) and the Muse Learns to Write (1986) Eric A. Havelock analyzes the transformation from orality to literacy in the Greek society in antiquity. Until Plato, a certain type of language dominated the Greek society, a language that, although found in literature, was essentially oral (Havelock 1986, 92-93):

Greek literature from its beginnings was composed in verse, not prose, and in Athens this continued roughly to the death of Euripides .... The content of the versified language-which, as versified, is storage language, regardless of the individual styles and purposes of individual writers-is uniformly mythic, meaning traditional .... Surviving orality also explains why Greek literature to Euripides is composed as a performance, and in the language of performance. The audience controls the artist insofar as he still has to compose in such a way that they can not only memorize what they have heard but also echo it in daily speech. The language of Greek classic theatre not only entertained its society, it supported it.

Havelock's main point is that all Greek literature until Plato was composed in verse so that it could be easily memorized, simply because orality was the means to pass on knowledge to the next generation. Generally speaking, adding rhyme, repetitions and beat helped illiterates store huge amounts of knowledge in memory. In fact, such systems were used by illiterate societies all around the world (Skafte Jensen 2011). The Greek version of this system originated from the Homeric formulae and meter, as discovered by Milman Parry in the beginning of the $20^{\text {th }}$ century (Parry and Parry 1971).

Now, when Nagy (2000) points to the fact that the colometric melodies employed by Aristophanes made it clear how to express verse, was it only to help foreigners coming to Alexandria? I think that the colometric melody has to be considered as a logical entry to a universe of beats, of easy retrievable literature by the very way it sounds. Consider the fact that almost all of the literature, excluding small parts of the late philosophy, in its actual phrasing contained a system that permitted it to be retrieved by its sound. Why on earth would the scholars of Alexandria, being the first in history to create a library to pass on knowledge from one generation to another (Bing 2008, 40) abandon the benefits of such a perfect system? Why not profit from it instead? The mechanics of the theatre in Athens could without difficulty be integrated in the mechanics of the library in Alexandria. One can even consider if the scholars were capable of avoiding it: The system could not be withdrawn from the literature it had created; it was the literature.

\subsection{Singing the structure of the library}

As the literature in the library could be sung, so could the structure of the library-theoretically. The catalog of ships in the second book of the Iliad is far from being the only catalog or list that singers had memorized and recited by

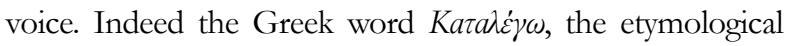
root of catalog, means both recite and list. What is important to understand, is that these two meanings do not oppose each other, lists were cataloged as they were sung, they were stored only in the memories of the singers. Surely, this practice changed in Athens around 400 BCE when lists began to be written down on scrolls, but the original potential did not disappear overnight. Memorizing lengthy lists was still both a praised rhetorical skill and a necessity for the illiterate. The Greeks did not lose awareness of the fact that lists had been passed on to them orally from generation to generation over a period of at least 400 years (Havelock 1986, 84). Quite the contrary: in Preface to Plato Havelock argues $(1963,43)$ that Plato excludes poetry from his Republic exactly because all branches of thinking were still influenced, and in Plato's point of view blurred, by the esthetics of orally transmittable poetry.

This raises a question: If orally-based learning skills, including the ability to recite catalogs, had such a huge intellectual impact even in the fall of Plato's life in Athens, could it be that a young Aristophanes in Alexandria some 
100 years later was still singing the catalog most useful to him? If Aristophanes did sing the Pinakes, this would be the last piece to the puzzle. It would explain not only why he as a living library could identify authors and works by small bits of literature read out loud, but that he could also find the scrolls containing the literature in the library. Why? Because the Pinakes mirrored the physical library. Singing the Pinakes meant singing the library, as structure.

No evidence of this is given, I must admit. Besides Vitruvius' story of the memory of Aristophanes (Jacob 2010), the Pliny the Elder's testimony of living libraries (Yates 1965) and Athenaeus's statement that all scholars had the content and structure of the library present in their memory (Jacob 2013) and finally all the arguments presented above, we are left to speculation. We cannot with certainty know whether the scholars had the structure of the library in their memory, even though all sources indicate it. I would like to point out that this constitutes an argument in itself: No source at all indicates the opposite of my view. In fact, opposing this idea is merely a result of thinking like Phillips (2010), Casson (2001) and Staikos (2000) that the library in Hellenistic Alexandria was organized like a modern, physical library per se. There is no evidence that the Pinakes was used as a modern, analog reference tool. It is simply assumed.

\subsection{The modernity of silent reading}

One final argument in support of the idea that the library was sung is the fact that silent reading was rare in the Alexandrian library. Actually, it might not even have oc- curred. Not until the tenth century did silent reading become the standard way of reading in the western world (Manguel 1996, 43). Until then, reading out loud or at least mumbling the words was the norm. One has to imagine the Alexandrian scholars as reading out loud the literature in the library, every time they read. Therefore, it seems fair to say that both structure and content of the library were sung, and that this was the order of the day. When the scholars recited the Pinakes or the literature out loud, this expressed the structure of the library. Done over and over again this must at some point have made the scholars reach a level where they most likely could sing the library without consulting the scrolls, but rely entirely on their memory. The process was made easier due to the fact that the literature was for the most part inherited oral literature, that was designed to be remembered, and that the Pinakes had its roots in the same tradition. In this way, I believe, the scholars singingly memorized the library.

\subsection{The mechanics of the memory library}

As I have just argued, I believe that the Hellenistic library of Alexandria could be sung, both its literature and its structure. Therefore, its physical structure, the dead library, must have been integrated with its counterpart, the structure in the memory of the scholars, the living library. Basically, the scholars, being living libraries, made use of themselves and the dead library as though they were one structure. They could sing both the structure of the library and the literature it contained from their memory, but they could rely on the physical library in the process of memo-

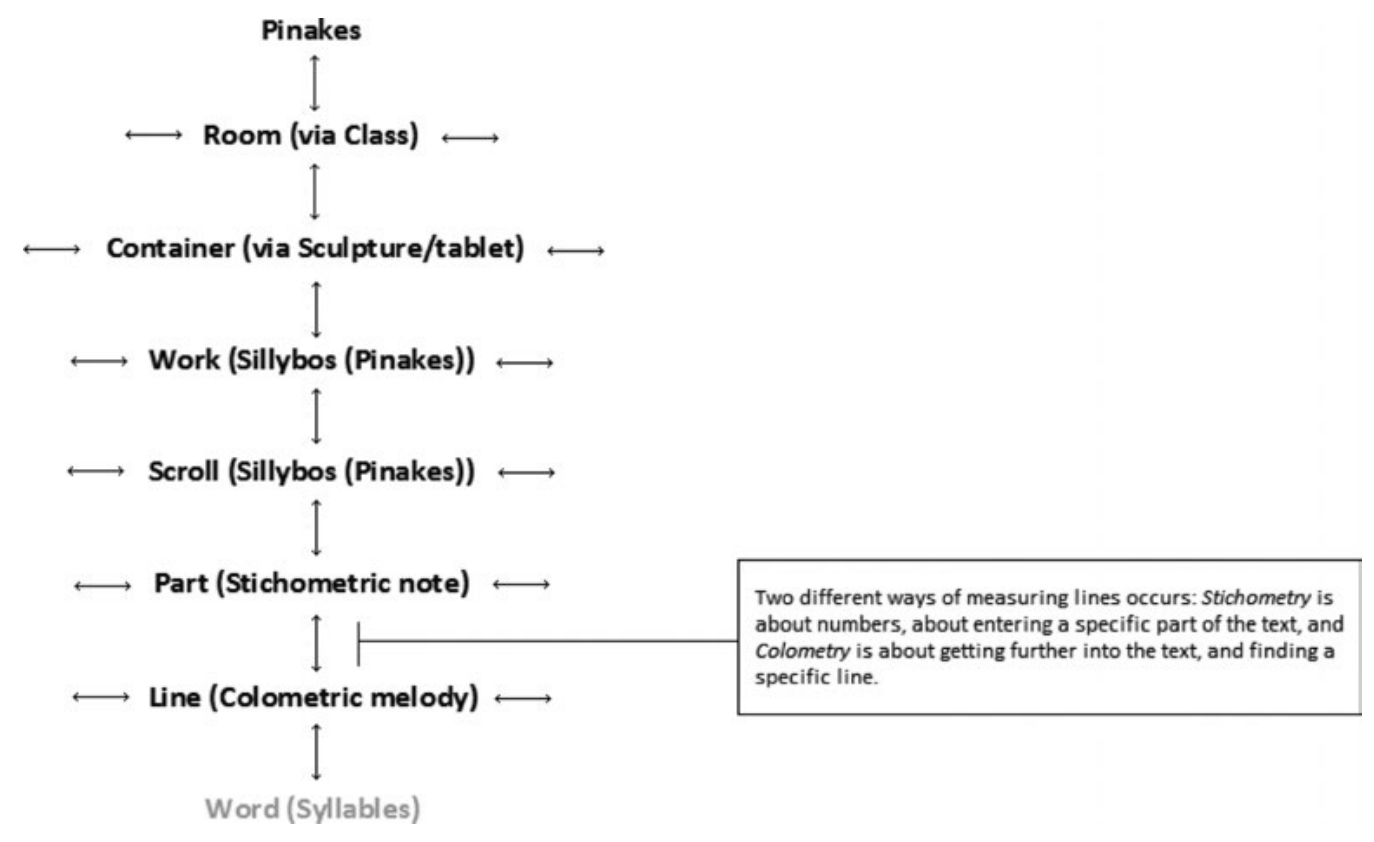

Figure 3: The mechanics of the memory library 
rization and indeed in cases of uncertainty and oblivion. The dead and the living library put together formed what I have chosen to call "the memory library." In order to illustrate this, I have simply added together the mechanics of the dead and the living library:

The mechanics of the memory library show both how classification and indexing, and information-seeking, in the Hellenistic library of Alexandria, worked.

To explain the mechanics of the memory library in a simple way, the reader must imagine being a living library. Imagine being Aristophanes. He knows the structure of the dead library by heart, since he knows the Pinakes by heart: they are identical. And that's it, really. The living libraries were able to browse the classes of literature in the Pinakes from memory, could go to specific rooms, authors, works, scrolls, parts and even lines in the work (perhaps even words) without moving. They browsed this structure in their minds. But if they wanted to, the living libraries could verify their content in the dead library, since their mechanics were compatible with each other's. The living library contained the dead library within it. And the dead library enabled the possibility of the living library.

The memory library had many advantages. It outmatched by far the mechanics of the dead library, because it could be browsed a lot faster than the dead library. Just imagine browsing 120 scrolls for an author, and then running to the area were the author was located, finding the right scroll and then, finally the right part. That is easier to do in thought than in reality, right? On the other hand think of the unreliability of human memory. It is easy to forget an author's literary class, exact phrasing and so on. Well, in this case the memory library was more reliable than the living library: It could not (in theory) lose its memory.

\subsection{Conclusion}

In the introduction, a specific understanding of how the Alexandrian library worked was rejected. Phillips (2010), Casson (2001) and Staikos (2000) seem to analyze the Alexandrian library by retrieving in it elements from the present reality of libraries. In this article, I have done the exact opposite. Instead of interpreting the library as similar to modern ones, I have claimed that the library was in fact a logic continuation of the Greek intellectual heritage. My point of departure was to follow Jacob (2010). He reflects on the memory of Aristophanes and how it must somehow mirror the organization of the library. In the present article I have followed his considerations, but widened the scope to all the scholars attached to the library. Accordingly, the article frames and outlines the living scholars as perusing their memory - a memory that mirrors the library's organization.
To defend the idea that these two libraries was in fact one integrated structure, I presented the argument of the voice. Havelock $(1963,1986)$ observed that Greek literature until Plato was unchallenged as orally transmittable. As a consequence, all of this literature could be stored and retrieved in memory by song. Included in this process were catalogs like the later Pinakes. I have argued, that if the Pinakes was actually sung by the scholars, the entire library could be sung, both its content and as a structure. This assumption is supported by the fact that reading in antiquity meant reading out loud (Manguel 1996). Therefore, the argument of the voice qualifies that the dead and the living library constituted one integrated structure. I have framed this structure as the memory library.

The memory library made classification and retrieval faster and more precise, than a library merely contained within a building or the human mind. As this article has demonstrated, the mechanics of the memory library reached its level of refinement before 200 BCE, by the time Aristophanes became the director of the library. At this point, the memory library had evolved into a 7 (maybe 8) step procedure: from the entire universe of knowledge, to the literary class, author, work, scroll, part, line and perhaps even right down to the specific word. I have argued that this structure could be perused in the mind of the scholar, and could always be verified, because the structure in the mind was also the structure of the physical library.

\section{References}

Barnes, Robert. 2000. Cloistered bookworms in the chiken-coop of the muses: The ancient library of Alexandria. In MacLeod, Roy M., ed., The Library of Alexandria: centre of learning in the Ancient World. London: I.B. Tauris Publishers, pp. 61-77.

Bing, Peter. 2008. The well-read muse: present and past in Callimachus and the Hellenistic poets. Ann Arbor, Michigan: Michigan Classical Press.

Blum, Rudolf. 1991. Kallimachos; The Alexandrian library and the origins of bibliography. Madison, Wisconsin: The University of Wisconsin Press.

Callmer, Christian. 1944. Antike bibliotheken. Rom: Svenska Institutet I Rom.

Cancik, Hubert, Schneider, Helmuth and Landfester, Manfred. 1996-. Der neue Pauly. Stuttgart: Verlag J.B. Metzler.

Canfora, Luciano. 1992. La Bibliothèque d'Alexandrie et l'histoire des textes. Liège: Cedopal.

Canfora, Luciano. 1990. The vanished library. Berkeley: University of California Press

Carruthers, Mary. 2008. The book of memory. Cambridge: Cambridge University Press. 
Casson, Lionel. 2001. Libraries in the ancient world. New Haven: Yale Nota Bene.

Coqueugniot, Gaëlle. 2007. Cofre, casier et armoire: la Kibôtos et le mobilier des archives et des bibliothèques greques. Revue archéologique 2: 293-304

Havelock, Eric A. 1963. Preface to Plato. Cambridge: Belknap Press, Harvard University Press.

Havelock, Eric A. 1986. The muse learns to write. New Haven: Yale University Press

Hoepfner, Wolfram. 2002. Die bibliothek eumenes' II. in pergamon. In Hoepfner, Wolfram, ed., Antike bibliotheken. Darmstadt: Verlag Philip von Zabern, pp. 41-52.

Irigoin, Jean. 2001. Le livre grec des origines à la Renaissance. Paris: Bibliothèque nationale de France.

Jacob, Christian. 2007. Alexandrie, IIIe siècle avant J.-C. In Jacob, Christian, ed. Lieux de savoir : espaces et communautés. Paris: Albin Michel, pp. 1120-45.

Jacob, Christian. 2010. Le bibliothécaire, le roi et les poètes. Athens dialogues e-journal 2: 1-17.

Jacob, Christian. 2013. The web of Athenaeus. Cambridge, Massachusetts: Harvard University Press.

Lerner, Fred. 2001. The story of libraries: from the invention of writing to the computer age. New York: Continuum.

Manguel, Alberto. 1996. A history of reading. New York: Penguin Group.

Meillier, Claude. 1979. Qallimaque et son temps. Lille: Université de Lille.

Nagy, Gregory. 2000. Reading Greek poetry aloud: Evidence from the Bacchylides Papyri. Quaerni urbinati di cultura classica 1: 7-28

Parry, Milman and Parry, Adam. 1971. The making of Homeric verse: The collected papers of Milman Parry. Oxford: Oxford University Press.

Parsons, Edward A. 1952. The Alexandrian Library: Glory of the Hellenic World. London: Cleaver-Hume Press Ltd.
Pfeiffer, Rudolf. 1949. Callimachus_Volumen I fragmenta. Oxford: Oxford University Press. I.

Pfeiffer, Rudolf. 1968. History of classical scholarship: from the beginnings to the end of the Hellenistic Age. Oxford: Oxford University Press.

Phillips, Heather. 2010. The great Library of Alexandria? Library philosophy and practice. Available http://unllib.unl. edu/LPP/phillips.htm

Platthy, Jenö. 1968. Sources on the earliest Greek libraries, with the testimonia. Amsterdam: A.M. Hakkert.

Skafte Jensen, Minna. 2011. Writing Homer: a study based on results from modern fieldwork. Copenhagen: Det Kongelige Videnskabernes Selskab.

Small, Jocelyn P. 1997. Wax tablets of the mind: cognitive studies of memory and literacy in classical antiquity. London: Routledge.

Staikos, Konstantinos. 2000: The great libraries: from Antiquity to the Renaissance. New Castle, Delaware: Oak Knoll Press.

Staikos, Konstantinos. 2004. The history of the library in western civilization: from Minos to Cleopatra. New Castle, Delaware: Oak Knoll Press.

Svenbro, Jesper. 1988. Phrasikleia: anthropologie de la lecture en grèce ancienne. Paris: Éditions la découverte.

Too, Yun L. 2010. The idea of the library in the Ancient World. Oxford: Oxford University Press.

Weber-Nielsen, Carsten. 1990. Mad \& vin i oldtiden Uuddrag af Athenaios' de larde middagsgaster. Copenhagen: Museum Tusculanum.

Witty, Francis J. 1958. The pinakes of Callimachus. Library quarterly 1: 132-8.

Witty, Francis J. 1973. The other pinakes and reference works of Callimachus. Library quarterly 3: 237-44

Yates, Francis A. 1965. The art of memory. London: Routledge 